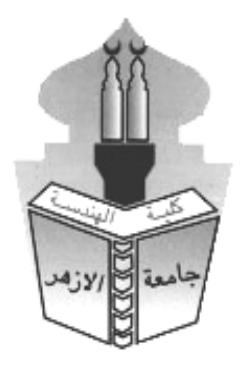

\title{
ASSESSING BIOPHILIC CRITERIA IN URBAN NEIGHBORHOODS OF SAUDI ARABIA: A CASE STUDY OF THE DIPLOMATIC QUARTER IN RIYADH CITY
}

\author{
Faisal Fahad Bin Sulaiman ${ }^{1}$ \\ ${ }^{1}$ King Saud University, Sustainable Urban Design \\ Email: fsouliuman@ksu.edu.sa
}

\begin{abstract}
One of the most important modern approaches used in urban development to achieve the principles and requirements of sustainability is the biophilic concept. There is a high recognition of the social and environmental benefits of connecting people with nature. Within the framework of the Kingdom of Saudi Arabia (KSA)'s endeavor to successfully achieve the 2030 Vision and the element of sustainability in urban life in residential neighborhoods, this study aimed to study and evaluate the elements of achieving the biophilic approach. Moreover, this study examines the biophilic design and planning criteria in the Diplomatic Quarter (DQ) in Riyadh City as a case study to determine to what extent the DQ achieves the selected biophilic approach criteria. The DQ analysis indicates that the biophilic criteria are highly achieved, which is reflected in the high percentage of green areas and parks and the great connectivity with local nature. Also, this study confirmed the importance of the biophilic concept in urban planning as a trending approach and paved the way to apply the biophilic approach in other urban communities and neighborhoods all over KSA.
\end{abstract}

Key words: Biophilia; Biophilic Design; Biophilic Planning; Sustainability; Neighborhood; Delphi Technique, Riyadh; Saudi Arabia, The Diplomatic Quarter (DQ)

$$
\begin{aligned}
& \text { تقييم معايير البيوفيليك في الأحياء الحضرية في المملكة العربية السعودية: }
\end{aligned}
$$

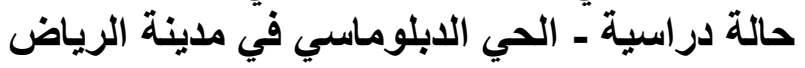

$$
\begin{aligned}
& \text { فيصل فهر بن سليمان } \\
& \text { جامعة الملك سعود ،التصميم الحضري المستدام } \\
& \text { fsouliuman@ksu.edu.sa بريد إلكتروني }
\end{aligned}
$$

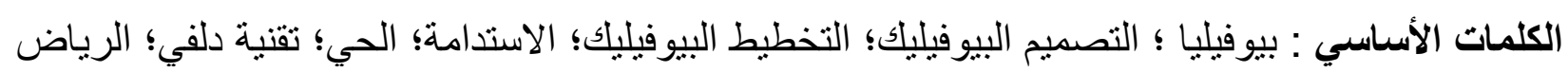

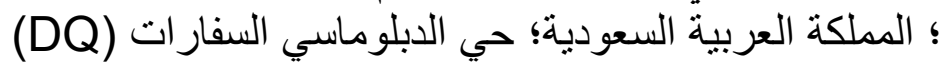




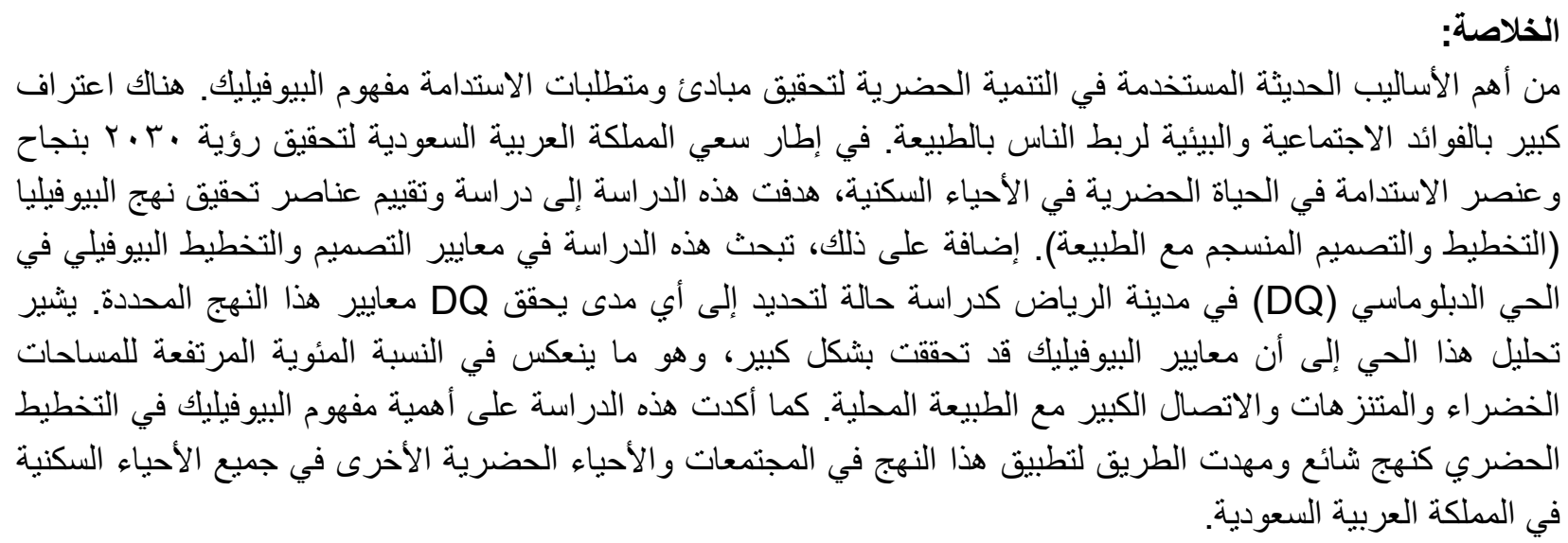

\section{INTRODUCTION}

Over the past decades, the Kingdom of Saudi Arabia (KSA) has undergone a dramatic change in terms of its urban environment owing to its booming economy and rapid urbanization, which shape a new modern urban form not in keeping with traditions, culture, and environmental conditions [1]. To adapt to these changes and achieve sustainability, Saudi Vision 2030 has set numerous goals to improve and make the urban environment healthier and more functional with a cultural identity [2]. One of these aims is to promote sustainability and provide the residents a health system, which represents a significant component in any urban form [3].

Here, the biophilic approach seems to be important as a national trend to achieve the different areas of sustainability - social, economic, physical, and environmental - in the KSA. This approach is considered to be one of the comprehensive approaches applied in most areas, regions, and countries, with the aim of achieving sustainability and sustainable development goals (SDGs) that most countries worldwide desire to achieve in one way or another. This research aims to assess the biophilic approach in urban neighborhoods in Riyadh, considering the Depolmatic Quarter (DQ) as a case study.

\section{BIOPHILIC DESIGN AND PLANNING}

Biophilia is a term that emerged in the early 1900s in medical dictionaries. It is defined as an innate behavior for the self or an instinctive driving force for survival [4]. "Bio" means everything that is organic, and "philia" means extreme or exaggerated love [4]. In other words, biophilia is a metaphor for the extended strong relationship between humans and nature which resulted from the humans' life development in various natural environments during the different eras of human history. Stephen Kellert and Edward Wilson defined this term as "a set of genetic tendencies to the value of nature that have a fundamental role in human well-being, material, emotional, intellectual, and moral" [4].

With the emergence of the term biophilia, numerous academic and scientific research have been conducted to demonstrate the various dimensions of this term:

First, in the medical dimension, the University of Washington, represented by Dr. Kathleen Wolf, has reviewed approximately 2800 academic articles explaining the relationship between the green urban spaces and public health and concluded that majority of these scholarly researches were from the 1990s to 2000s. This indicates that biophilia has already been a trend since the last decade [47]. Moreover, the importance of biophilia in health has been confirmed in numerous studies, such as the study published in the British Journal of Sports Medicine, wherein the Edinburgh University students were asked to wear electroencephalography caps and walk for 30 min through many urban areas (shopping areas, parks, green spaces, and busy streets). This study measured the general changes in their brains. The results confirmed that while moving into green spaces and areas, the students' brain exhibited higher meditation, lower frustration, and arousal [48]. Moreover, a series of experiments have been conducted in the University of Utah. The 
results of these experiments confirmed that the participants were more creative and responded effectively to problem-solving tasks when exposed to scenes of urban green landscape [49].

Second, in the economic dimension, there is a long and extensive body of economic researches demonstrating the benefits and value of using the natural and biophilic idea. For example, the San Francisco government calculated the economic value and benefits bestowed by green spaces, parks, and other green areas in 2014, which was around $\$ 959$ million [50]. Moreover, the study by Donovon and Burty (2010), which investigated the economic effects of trees on the value of homes in Portland, confirmed that the presence of trees added a great value to homes in Portland (around $\$ 1.35$ billion) [51].

Finally, in the urban environment dimension, the importance of the biophilic approach is reflected in the context of biophilic design and planning in numerous countries and cities. With the development of the biophilia theory, Stephen Kellert, a scientist and a social ecology professor at Yale University, coined the term biophilic design and planning in the context of the green building movement. He proposed biophilic design and planning as a dimension of restorative environmental design [6]. Biophilic design and planning aims to translate and gain benefits from the environment in urban design and planning based on the enhancement of integration and interest between people and nature in a systematic and active way [7].

Biophilic design and planning consists of the interactions of four main scientific areas: environmental aesthetics, human psychology, environmental planning, and urban design (Figure 1). These interactions constitute some of the subtopics that make up the scientific scope of the theory, namely, environmental preferences, restorative environments, urban aesthetics, and sustainable urbanism [8].

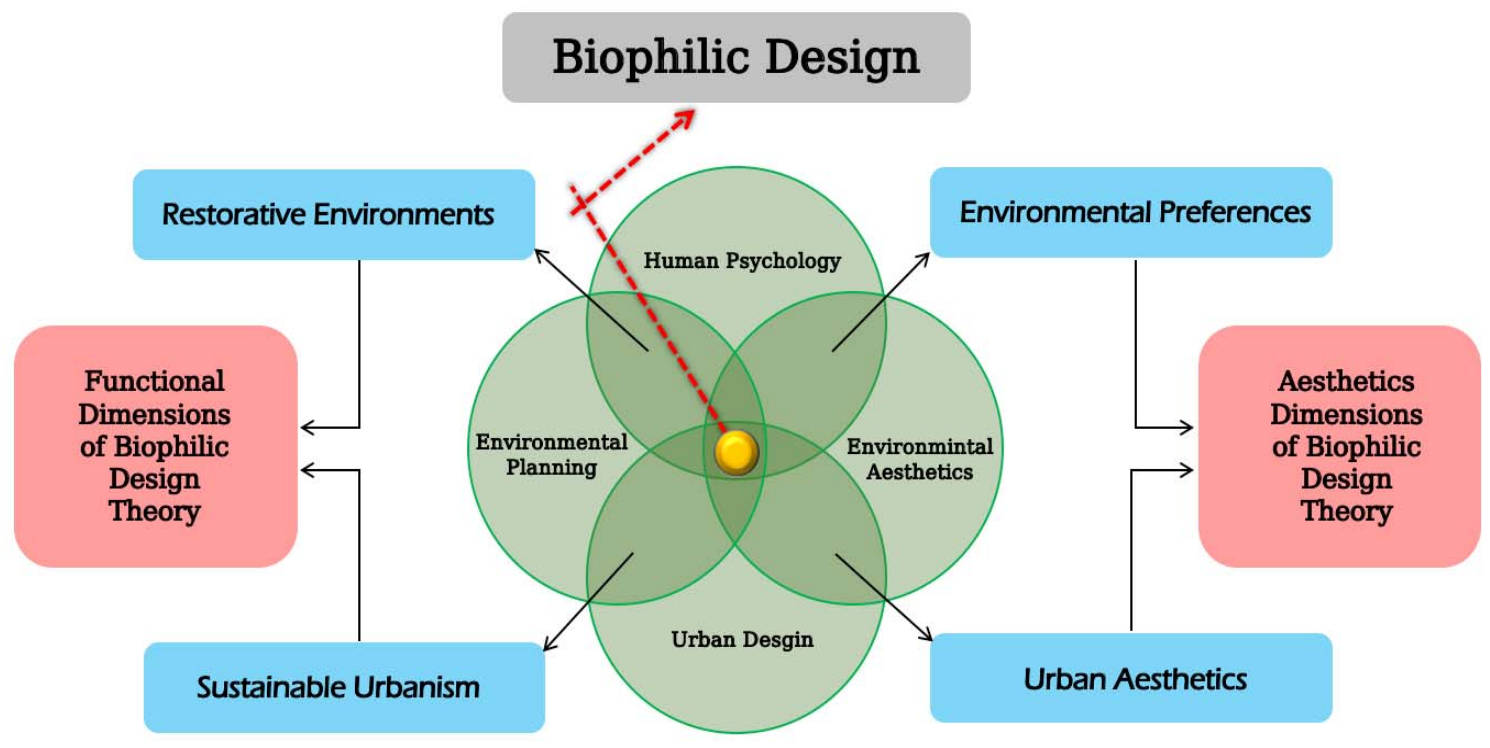

Fig 1. The four main scientific areas which formed the biophilic design (Source: Author based on [8])

Biophilic planning and design criteria are classified according to the scale of the building, block, street, neighborhood, community, and region. This is the most important classification according to the founder of the biophilic concept, Stephen Kellert (Table 1) [45]. 
Table 1. Use of the scale approach to classify the biophilic planning and design criteria. Source: [45]

\begin{tabular}{|c|c|}
\hline Scale & Biophilic Design Elements \\
\hline \multirow[t]{5}{*}{ Building } & Green rooftops \\
\hline & Sky gardens and green atria \\
\hline & Rooftop garden \\
\hline & Green walls \\
\hline & Daylit interior spaces \\
\hline \multirow[t]{3}{*}{ Block } & Green courtyards \\
\hline & Clustered housing around green areas \\
\hline & Native species yards and spaces \\
\hline \multirow[t]{7}{*}{ Street } & Green streets \\
\hline & Sidewalk gardens \\
\hline & Urban trees \\
\hline & Low-impact development \\
\hline & Vegetated swales and skinny streets \\
\hline & Edible landscaping \\
\hline & High degree of permeability \\
\hline \multirow[t]{6}{*}{ Neighborhood } & Stream daylighting, stream restoration \\
\hline & Urban forests \\
\hline & Ecology parks \\
\hline & Community gardens \\
\hline & Neighborhood parks and pocket parks \\
\hline & Greening grayfields and brownfields \\
\hline \multirow[t]{6}{*}{ Community } & Urban creeks and riparian areas \\
\hline & Urban ecological networks \\
\hline & Green schools \\
\hline & City tree canopy \\
\hline & Community forest and community orchards \\
\hline & Greening utility corridors \\
\hline \multirow[t]{4}{*}{ Region } & River systems and floodplains \\
\hline & Riparian systems \\
\hline & Regional greenspace systems \\
\hline & Greening major transport corridors \\
\hline
\end{tabular}

The classifications divide the criteria into a group of patterns (14 patterns) organized into three main categories: (a) nature in the space, (b) natural analogs, and (c) nature of the space (Table 2) [52]. 
Table 2. Classification of the biophilic planning and design criteria into 14 patterns Source: [52]

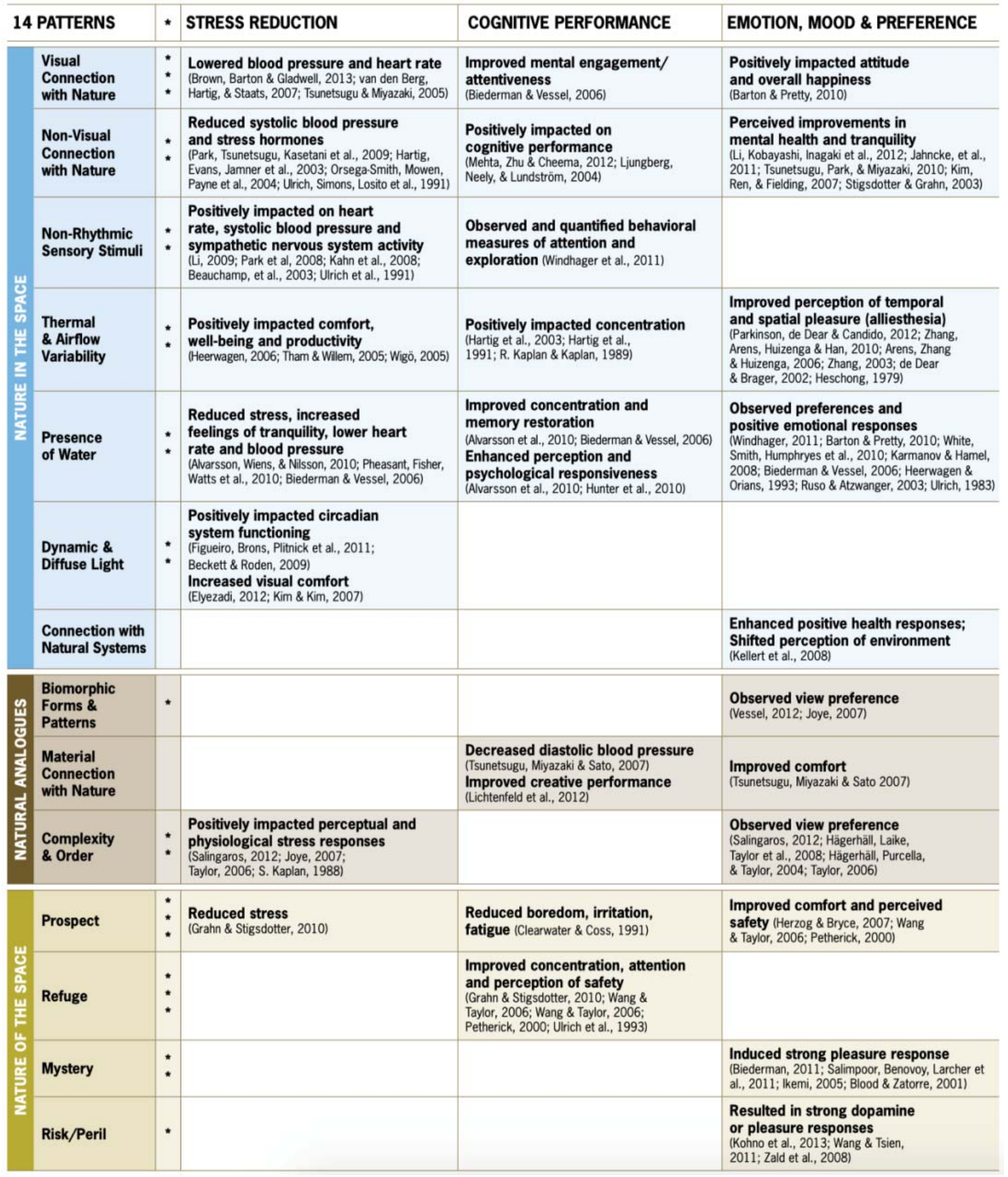

The biophilia concept as an urban perspective exists in numerous countries worldwide. It is considered to be a significant solution for improving the quality of life and achieving sustainability in residential neighborhoods. For example, Singapore uses the biophilic urbanism approach to transform from being a "Garden City" to a "City in a Garden" [41]. Singapore achieves this approach using two main strategies: creation of more natural systems between buildings in the neighborhoods and creation of natural systems on building facades. Many projects and initiatives have fulfilled these two strategies, such as the streetscape plans (creating continuous tree canopy above all major roads), park connectors (connecting all major green areas with a linear island park network), horticulture park, community gardens, and ABC of water 
management [41]. Thus, Singapore is currently considered as one of the world's best example of a "biophilic city" [42].

Another example is New York, where a study has been conducted to determine the effect of biophilic and non-biophilic spaces on workers. In this study, people were interviewed during their lunch breaks at four sites: two biophilic (Elevated Acre and Bowling Green) and two nonbiophilic (Pearl Street and Broad Street) spaces in the Manhattan neighborhood [43]. The results, in general, indicated that people were more motivated to walk long distances to biophilic spaces than to non-biophilic ones [43].

Moreover, there are many other worldwide case studies applying the biophilic approach in urban design and planning to achieve sustainability and improve the quality of life. such as those conducted in Chicago, USA, whose government started urban green initiatives with the aim of achieving biophilic urbanism [42]; Toronto, Canada, which established many environmental programs and strategies to improve the quality of life and achieve biophilic principles [42]; and Berlin, Germany, where about $1 / 3$ of the area is a natural habitat area with several biophilic and environmental mechanisms [42].

\section{BIOPHILIC DESIGN AND PLANNING IN SAUDI ARABIA (URBAN PERSPECTIVE)}

With the KSA's relentless pursuit of development and achievement of sustainability in various national fields, Saudi Vision 2030 came as a roadmap to achieve various development goals to make the KSA a world-class country [10]. This vision was based on three main pillars: a vibrant society, a thriving economy, and an ambitious nation [2]. The National Transformation Program (NTP) emerged from this ambitious vision, which aims to achieve the desired targets of Saudi Vision 2030 [11]. The NTP includes 27 government institutions that work as Vision Realization Programs (VRPs) and consists of eight main themes [10]. This study aimed to contribute to the achievement of the second theme, which reflects the improvement of living standards and safety (Table 1).

Table 3. The strategic objectives of the second theme of the National Transformation Program (NTP)

\begin{tabular}{ll}
\hline \multicolumn{1}{c}{ NTP Theme } & \multicolumn{1}{c}{ Strategic Objectives } \\
\hline 2. Improve Living Standards and & 2.1 Improve the quality of services provided in the cities in KSA. \\
Safety & 2.2 Improve the urban landscape in the cities in KSA. \\
& 1.3 Enhance traffic safety. \\
& 2.4 Reduce all types of pollution. \\
2.5 Improve the living conditions of expatriates. & Source: Author based on [11]
\end{tabular}

To achieve the second theme of the NTP, which aims to achieve sustainability in the urban environment in the KSA, several initiatives have been established in this context, such as Humanizing Cities, Quality of Life Program, and Green Riyadh Project (Figure 2). Humanizing Cities is considered as a modern term with the aim of making cities more suitable for people and enhancing the friendliness of the city [12]. In other words, Humanizing Cities is an initiative to enhance the human dimension in cities through the provision of facilities and activities that would make life more attractive and humane [13].

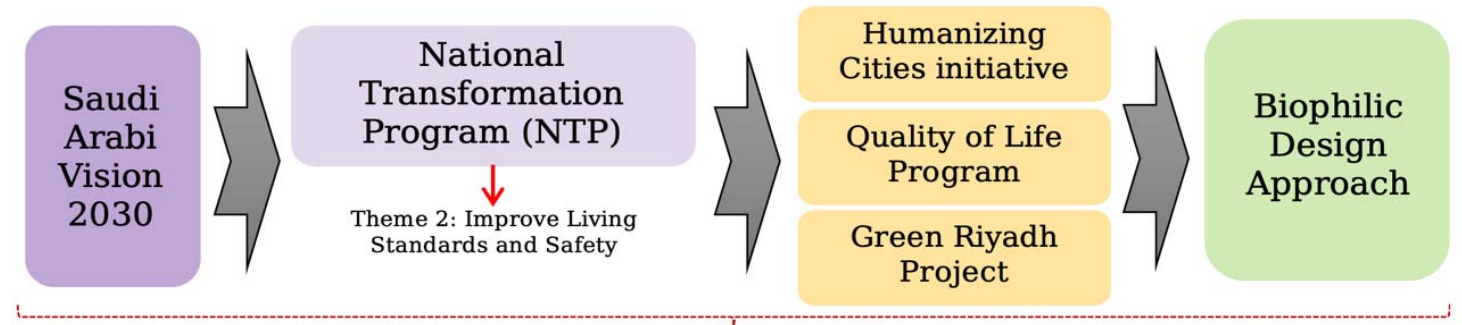

Sustainability Framework

Figure 2. The biophilic design as an approach to achieve Saudi Vision 2030 (Source: Author) 
Although studies on biophilic design in the KSA are scarce, Saudi municipalities are currently seeking to use the biophilic concept as an approach to achieve the goals of Humanizing Cities and improve the quality of urban life in the cities in the KSA. By applying the biophilic approach, local municipalities support the interaction between people and nature and thus achieve the principle of sustainability. This leads to the achievement of the idea of human cities that are friendly. Riyadh was one of the first cities to apply this approach in its different residential neighborhoods, which represent the basic unit of the urban form and the city fabric [15] that appeared in the planning and design of the Diplomatic Quarter (DQ).

\section{MATERIALS AND METHODS}

This study aimed to investigate and assess the achievement of the main criteria of the biophilic design and planning in Riyadh's neighborhoods. To achieve this target, the study should answer two main questions: (1) What are the most affected biophilic design and planning criteria in Riyadh's neighborhoods? (2) To what extent the DQ in Riyadh achieve the selected biophilic design and planning criteria?

To answer these questions, this study employed two methods. The first question can be answered using a questionnaire based on a research workshop employing the Delphi technique. The second question assesses the achievement of the biophilic criteria in the chosen study area; it can be answered using an on-site observation survey and through a review of the related studies, reports, and references.

\subsection{CASE STUDY}

As presented in Figure 3, the DQ, also known as Al Safarat neighborhood in Riyadh, has been selected as the study area to analyze the biophilic design and planning criteria.

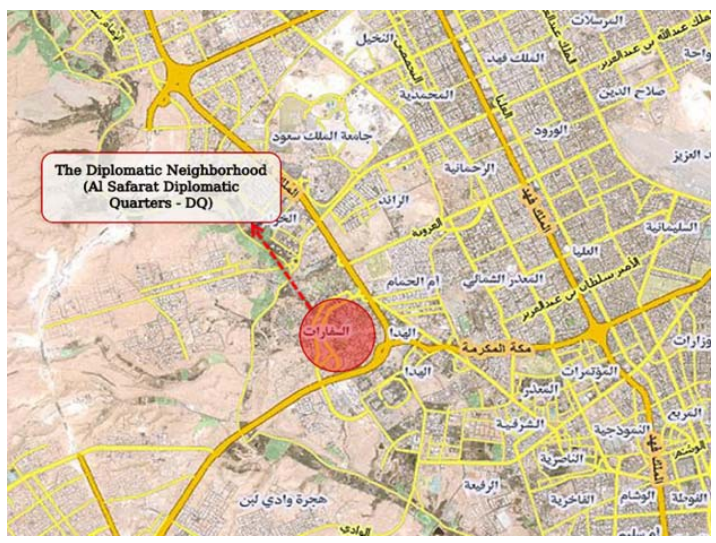

(a)

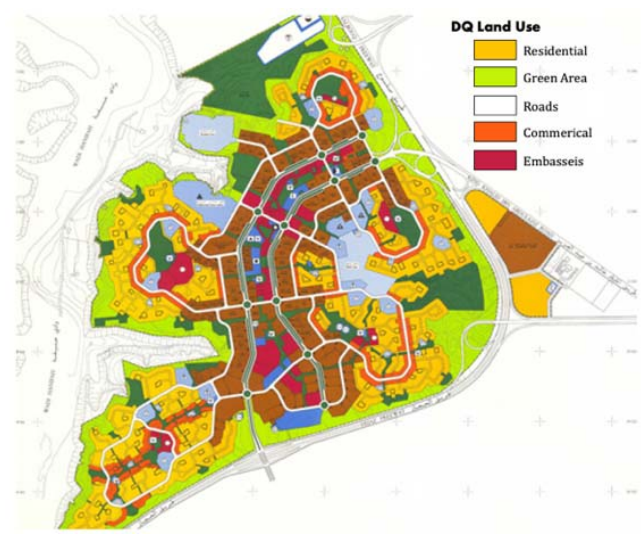

(b)

Figure 3. The Diplomatic Quarter, DQ); (a) the location of the DQ in Riyadh; (b) the original plan of the DQ (Source: [9])

The Diplomatic Quarter is part of Wadi Hanifa. It is located in the southwest area of Riyadh, about $12 \mathrm{~km}$ from the city center. It covers an area of 800 ha and has 25,000 inhabitants [17] (Table 2). Moreover, the DQ encompasses most of the foreign diplomatic embassies and missions in the KSA. It is a large residential district, where $22.2 \%$ of the land was set aside for residential purposes, which includes five sub-residential complexes; the capacity of each of them ranges from 3000 to 6000 people [9].

Table 4. The key features of the DQ, Riyadh, KSA. Source: [9]

\begin{tabular}{ccc}
\hline Location & Area & Status \\
\hline $\begin{array}{c}\text { Southwest of Riyadh } \\
(12 \mathrm{~km} \text { away from the city center })\end{array}$ & 800 ha & Built and ongoing \\
\hline Population & Land use & Number of parks \\
\hline & $-30.9 \%$ Green Areas & 17 Park \\
\hline
\end{tabular}


The study area has been chosen after analyzing the masterplan of Riyadh. This is generally because the main biophilic design and planning criteria appear in the DQ. Moreover, many detailed criteria were considered in choosing the DQ as the study area for this study, such as the following:

- The DQ represents a reflection of one of the most important policies and implementing procedures of the strategic plan of Riyadh City 2030, which enables the creation and establishment of new suburbs that apply the new planning patterns, considering the environmental dimension. Conversely, the DQ represents a different design for the neighborhoods in Riyadh City [15].

- The DQ represents a comprehensive modern model of urban patterns of the neighborhoods in Riyadh. These patterns are of four main types: (a) grid pattern; (b) rectangular pattern 2 * $2 \mathrm{~km}$; (c) traditional pattern; and (d) cul-de-sac pattern [19] (Figure 5). The DQ is an example of the fourth pattern; it was planned with high-quality urban design guidelines.
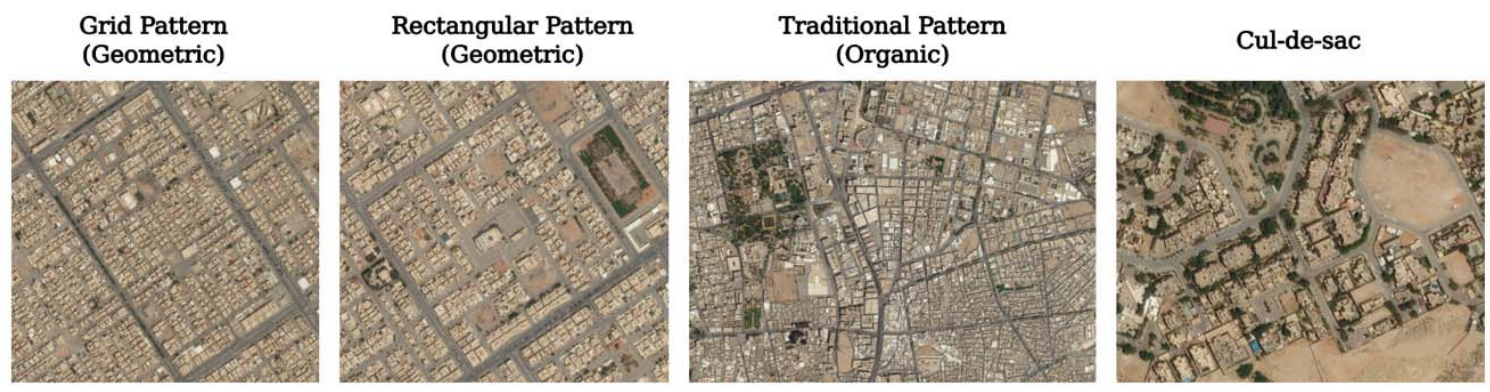

Figure 4. The patterns of the neighborhoods in Riyadh City (Source: Author)

\subsection{DATA COLLECTION AND DATA ANALYSIS}

The following section is devoted to the data collection and analysis used in this research. This section includes two areas of concerns. First is to identify the most important Biophilic criteria in the Riyadh neighborhoods and the second is to assess the Biophilic Criteria in the Diplomatic Quarter (DQ), Riyadh as the case study of this research.

\subsubsection{IDENTIFY THE MOST IMPORTANT BIOPHILIC CRITERIA IN THE NEIGHBORHOODS IN RIYADH}

In the first stage of data analysis, the Delphi technique was employed to select the most important biophilic criteria affecting the urban environment of Riyadh residential neighborhoods. In general, the biophilic design and planning criteria differ in terms of their division and classification from country to country and from an expert to another. This study employed a research workshop consisting of specialists and experts in the field, with the aim of reviewing all these classifications and the sub-branches thereof and merging some of them to achieve a set of integrated standards.

The Delphi technique is one of the most important scientific and academic methods that depend on experts to obtain the best possible results [20]. This technique is based on the idea that group thinking is much better than an independent thinking. In this technique, questionnaires and surveys are sent to a group of experts, and in the light of their answers, new questions are identified. Moreover, the rounds are repeated, so that the answer becomes a question for another expert. Thus, we obtain the most accurate outcomes from the group of experts, and their proposals are reassessed through documentation and amendment of the answers only, without meeting of the experts; obtaining a relative agreement of opinion mainly depends on the rotation 
of the questionnaires. The more selected experts and their diversity are examined, the better and more accurate the results [21].

After the selection of the experts, the second stage of the Delphi technique is applied by conducting workshops through three basic rounds: brainstorming (R1), narrowing down (R2), and evaluating (R3). In the first stage (R1), a workshop is conducted between all study participants with the aim of choosing a large group of biophilic criteria in general; then, the experts add their comments and suggestions and exclude the criteria that are unclear or that have more than one interpretation. In the second stage (R2), the experts are asked to refine the criteria derived from R1 and choose the appropriate ones to enable Riyadh City to reach the final criteria before answering the final questionnaire. In the third stage (R3), a survey is conducted on the experts to determine the relative importance of each of the selected criteria in R2 and to identify the most important criteria affecting the application of the biophilic approach in Riyadh [22].

In this study, 25 experts participated, and they were a highly diverse group: urban planners (3), urban designers (5), environmental experts (2), architects (3), and facilities manager (1). All of them had experience in urban development and planning in the KSA. Online workshops (due to the COVID-19 situation) were conducted to obtain various criteria for the application of the biophilic approach in residential neighborhoods in Riyadh.

Through these workshops, and after the classification in the first stage, the experts found a variety of criteria that achieve the biophilic concept in the urban field. These criteria are divided broadly into the following: (a) planning criteria, which are concerned with the planning dimension in cities, and (b) design criteria, which are concerned with the internal standards for the urban design in parts of the cities [23]. The neighborhoods, which are the focus of this study, should achieve the biophilic planning criteria as an integral part of Riyadh City, as well as the interior biophilic design criteria as part of an urban community. Subsequently, through several rounds of discussion, the experts reached to seven biophilic planning and design criteria, which consisted of 15 sub-criteria (Table 6), to assess the achievement of the biophilic approach in the DQ in Riyadh.

Table 5. Biophilic planning and design criteria

\begin{tabular}{|c|c|c|c|}
\hline \multicolumn{4}{|c|}{ *Biophilic Planning and Design Criteria } \\
\hline \multirow{14}{*}{$\begin{array}{c}\text { Planning } \\
\text { Criteria }\end{array}$} & \multirow{3}{*}{ Nature Outside the Neighborhoods } & \multicolumn{2}{|c|}{ Transitional Areas } \\
\hline & & \multicolumn{2}{|c|}{ Tiered Planning Zones } \\
\hline & & \multicolumn{2}{|c|}{ Building Heights and Skyline } \\
\hline & Ecological Corridors & \multicolumn{2}{|c|}{ Blue and Green Corridors } \\
\hline & \multirow{4}{*}{ Ecological Areas } & \multicolumn{2}{|c|}{ Surfaces and Green Buildings } \\
\hline & & \multicolumn{2}{|c|}{ Local Gardens } \\
\hline & & \multirow{2}{*}{\multicolumn{2}{|c|}{$\begin{array}{l}\text { Various Green Areas } \\
\text { Natural Area Inside the Urban Area }\end{array}$}} \\
\hline & & & \\
\hline & \multicolumn{3}{|l|}{ Land Use } \\
\hline & \multirow{5}{*}{ Planning Management } & \multicolumn{2}{|c|}{ Waste Management } \\
\hline & & \multirow{4}{*}{$\begin{array}{l}\text { Wildlife } \\
\text { Management }\end{array}$} & Selection and Classification \\
\hline & & & Prevent and Reduce Damage \\
\hline & & & Identify and Control Habitats \\
\hline & & & Control Interaction \\
\hline \multirow{10}{*}{ Design Criteria } & \multirow{2}{*}{ Building and Space Designs } & \multicolumn{2}{|c|}{ Building Designs } \\
\hline & & \multicolumn{2}{|c|}{ Urban Space Designs } \\
\hline & \multirow{8}{*}{ Landscape Elements } & \multirow{2}{*}{ Paths } & Design \\
\hline & & & Material \\
\hline & & \multirow{5}{*}{$\begin{array}{l}\text { Ecological } \\
\text { Elements }\end{array}$} & Land Cover \\
\hline & & & Animal Habitats \\
\hline & & & Water Features and Elements \\
\hline & & & Geological Landforms \\
\hline & & & Natural Lighting \\
\hline & & \multicolumn{2}{|c|}{ Courtyard Designs } \\
\hline
\end{tabular}

Source: Author $-{ }^{*}$ See the full details and features of these criteria in Appendices A and B 
The selected criteria have also taken three main considerations:

- These criteria should be suitable for the nature of the built environment in the residential neighborhoods in Riyadh, which may give more importance to some criteria than the others or may incorporate some of the sub-criteria into the major ones.

- The various experiences of the selected experts participating in the workshops, that lead to many discussions that ended with the filtering and merging of these criteria.

- The naturalness of the evaluation of the biophilic design and planning approach in Riyadh in general and the DQ in particular, which is considered to be the first urban environment using this approach, renders the selection and installation of the criteria used in the measurement process different from any of the classifications of the criteria mentioned previously.

\subsubsection{ASSESSING THE BIOPHILIC CRITERIA IN THE DIPLOMATIC QUARTER (DQ), RIYADH}

In this study, the second stage of data analysis is the assessment of the selected biophilic criteria in the DQ in Riyadh. The achievement of these criteria in the urban environment in this neighborhood is investigated (Table 3 ). 
Table 6. Assessing biophilic planning and design criteria in the Diplomatic Quarters (DQ) in Riyadh

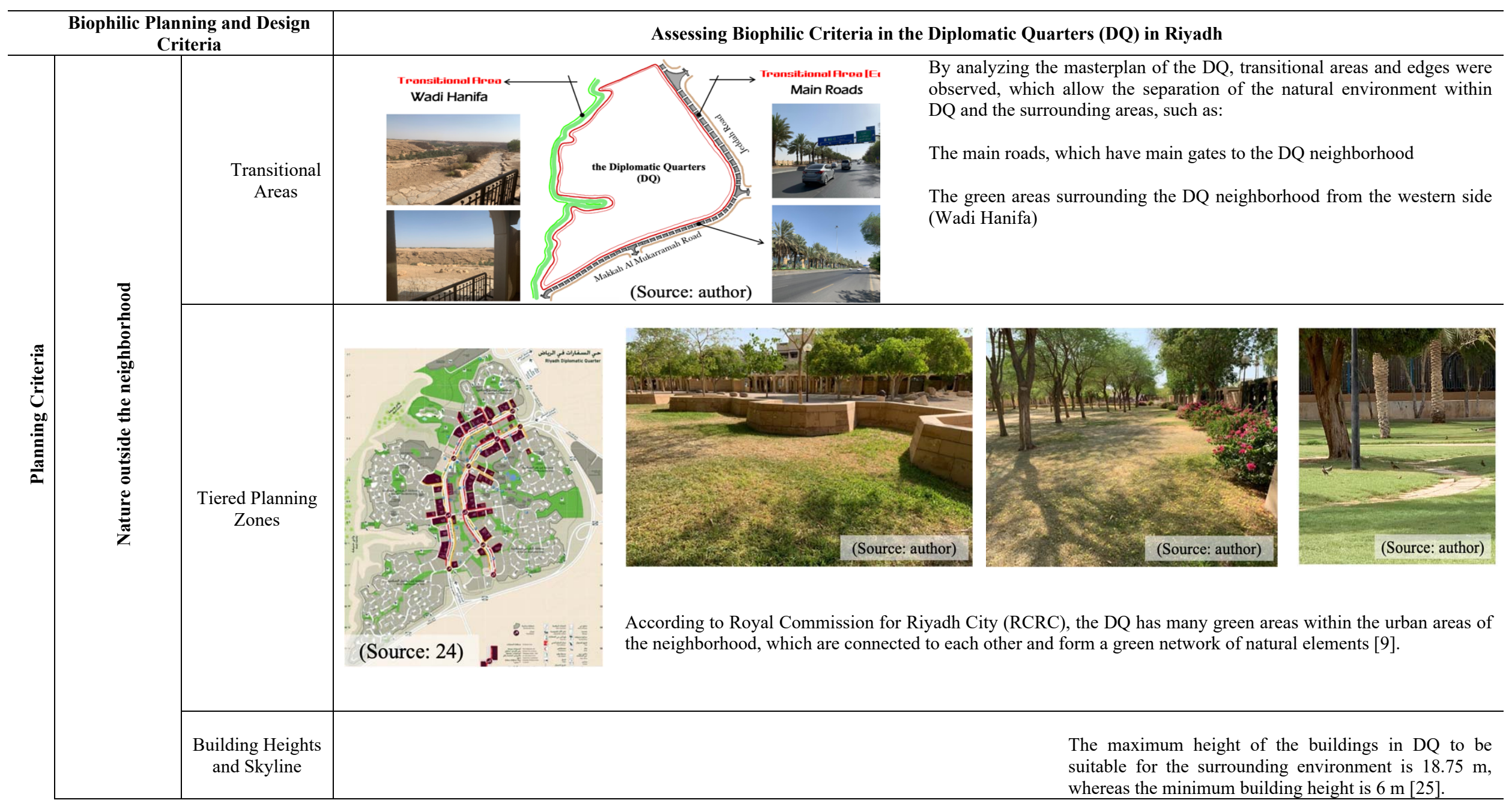




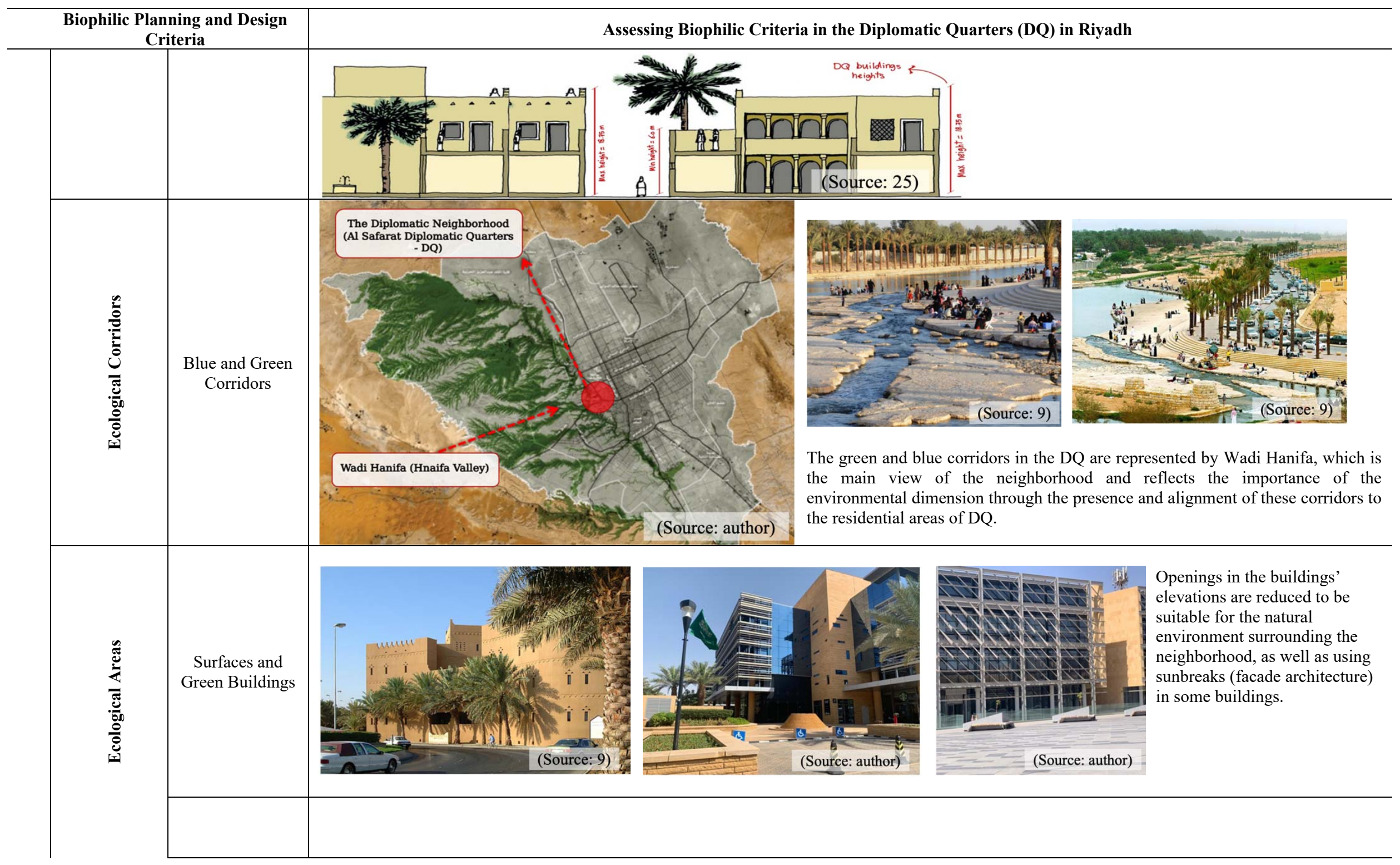




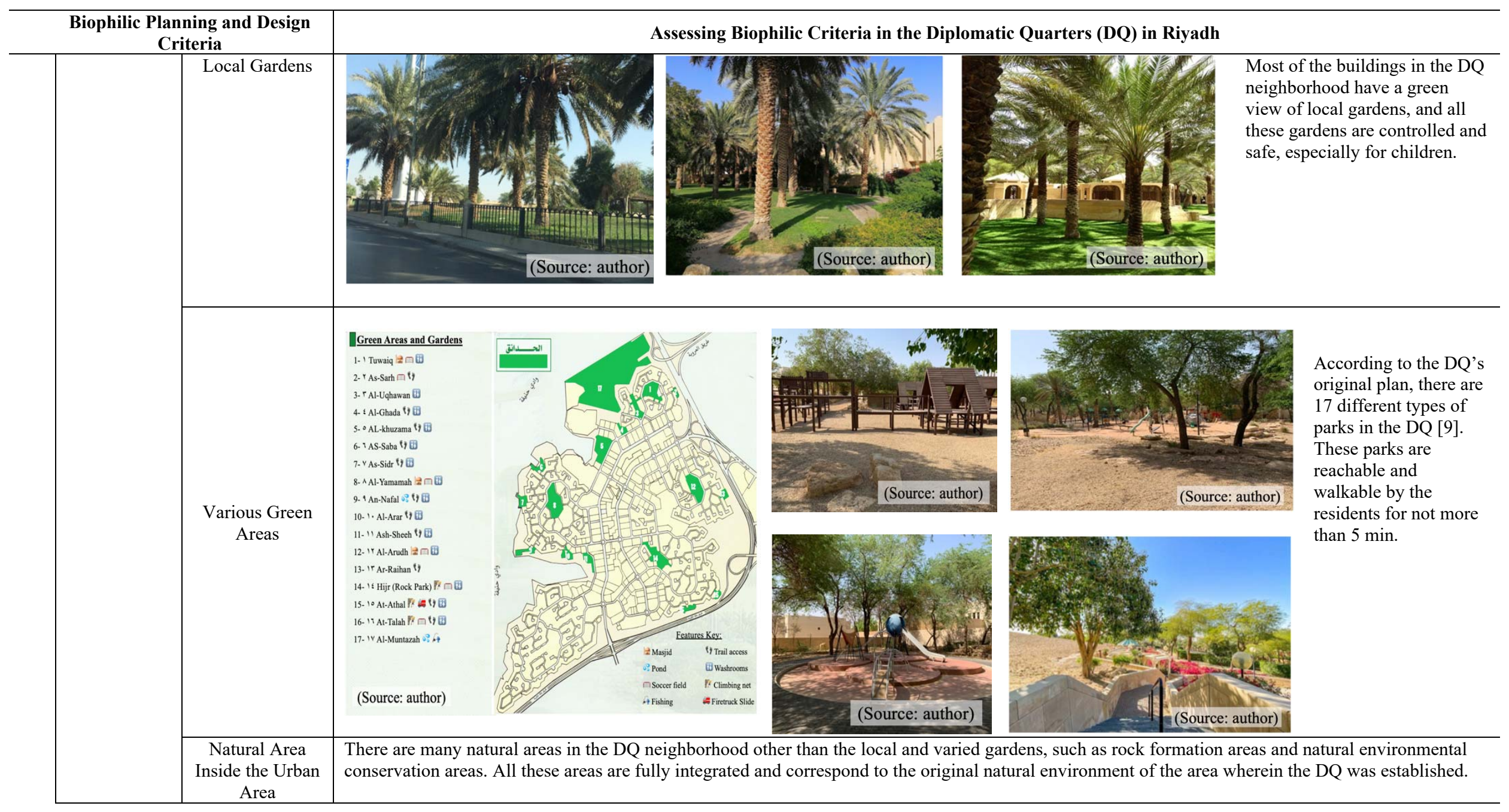




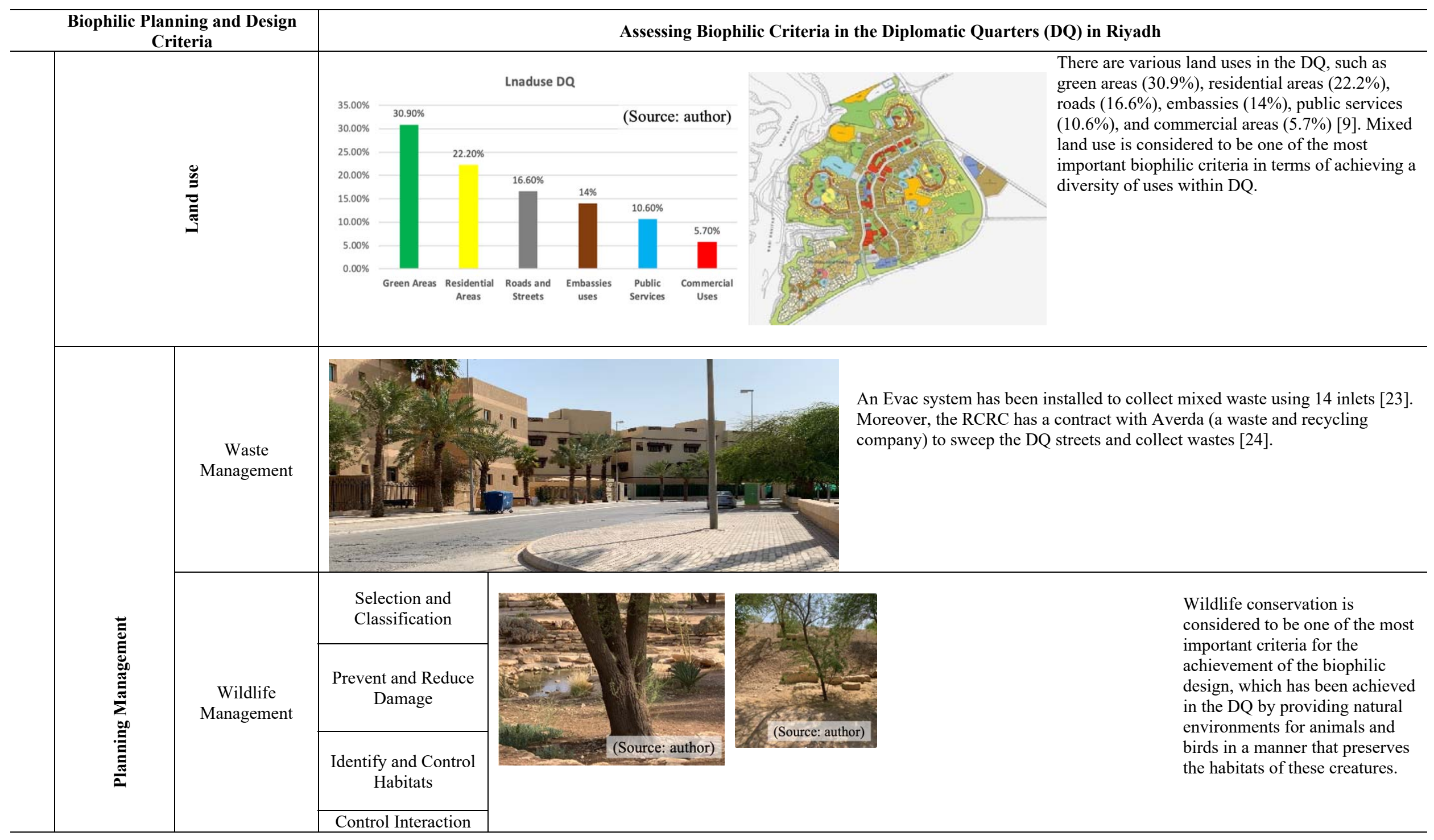




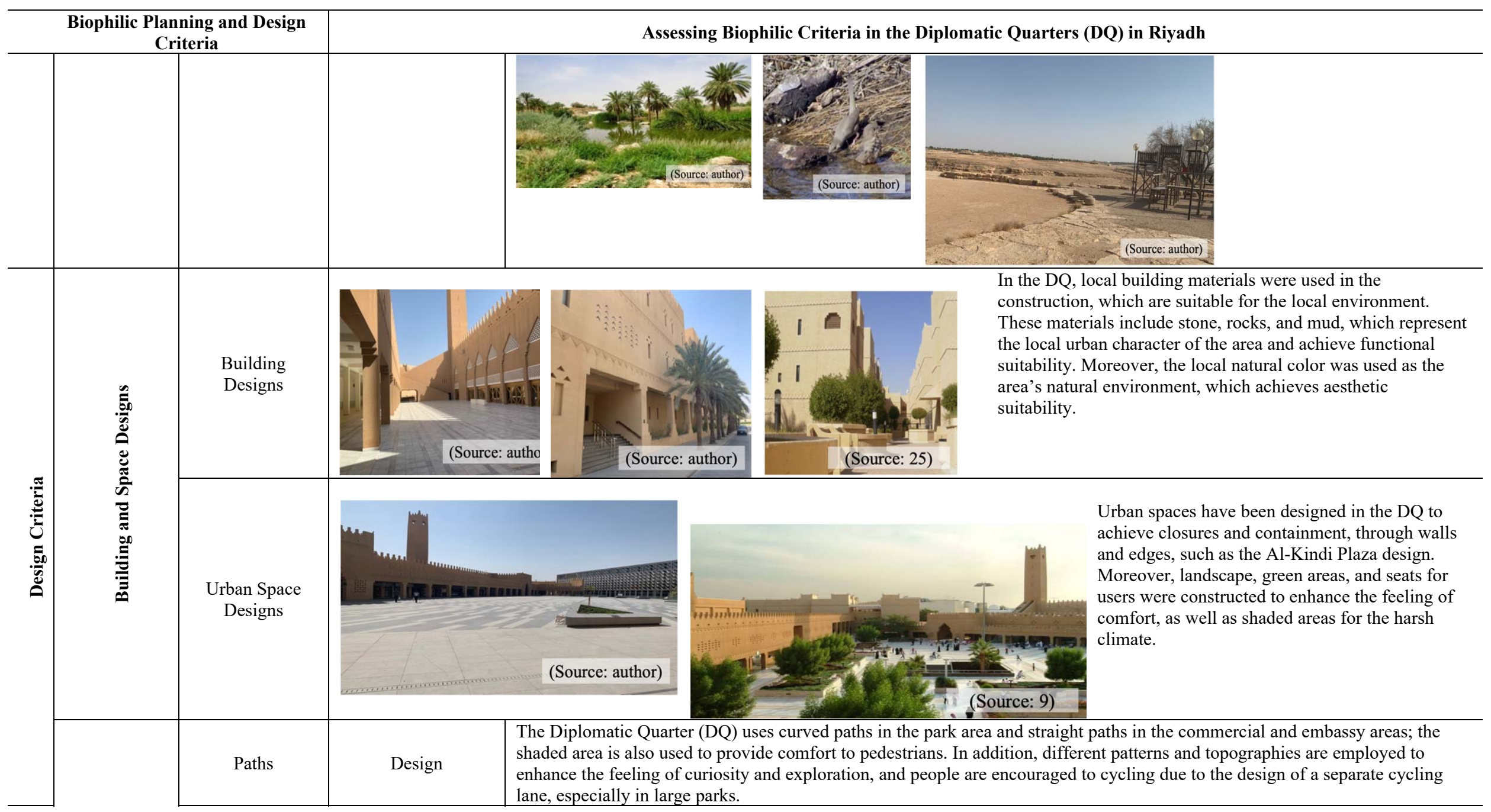




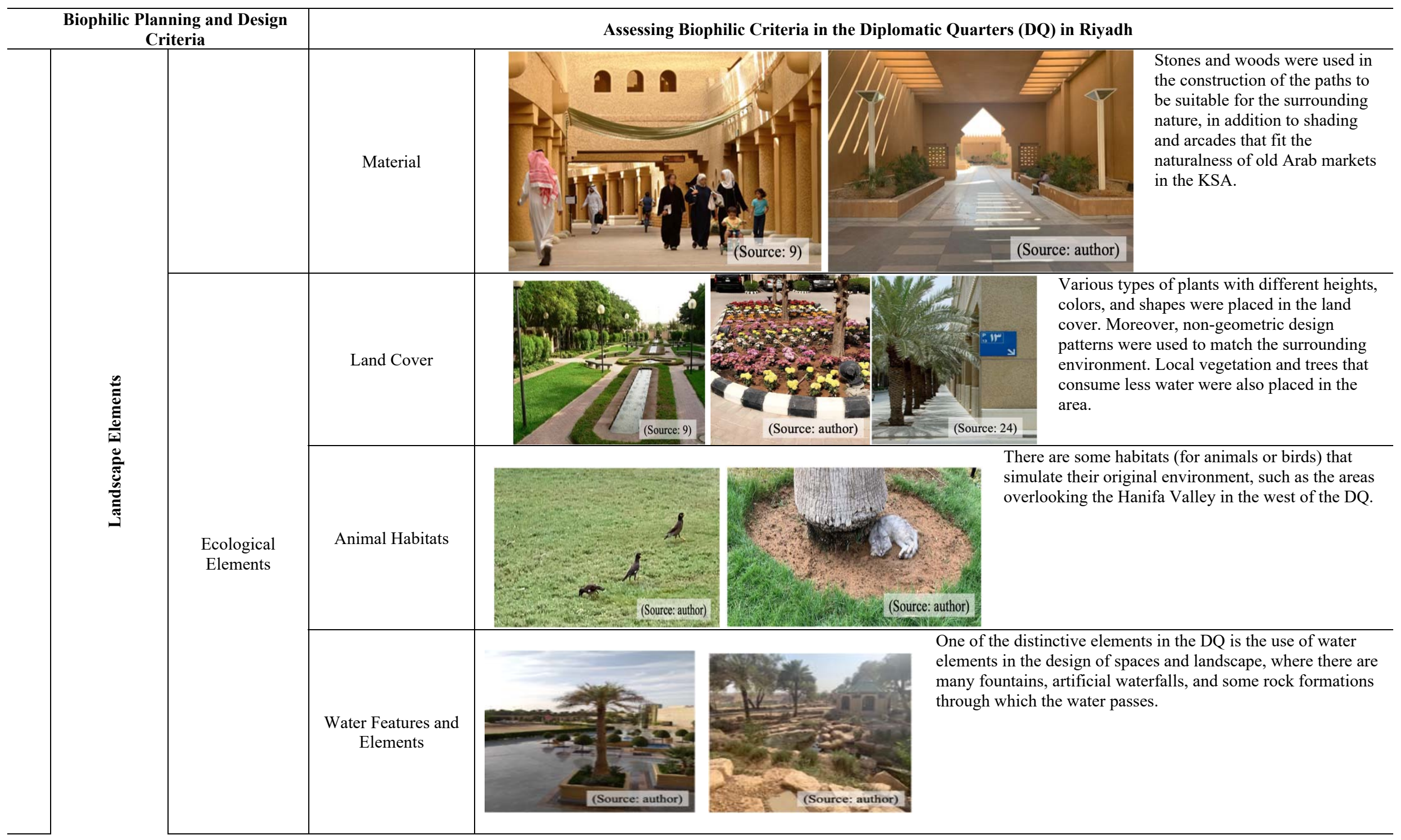




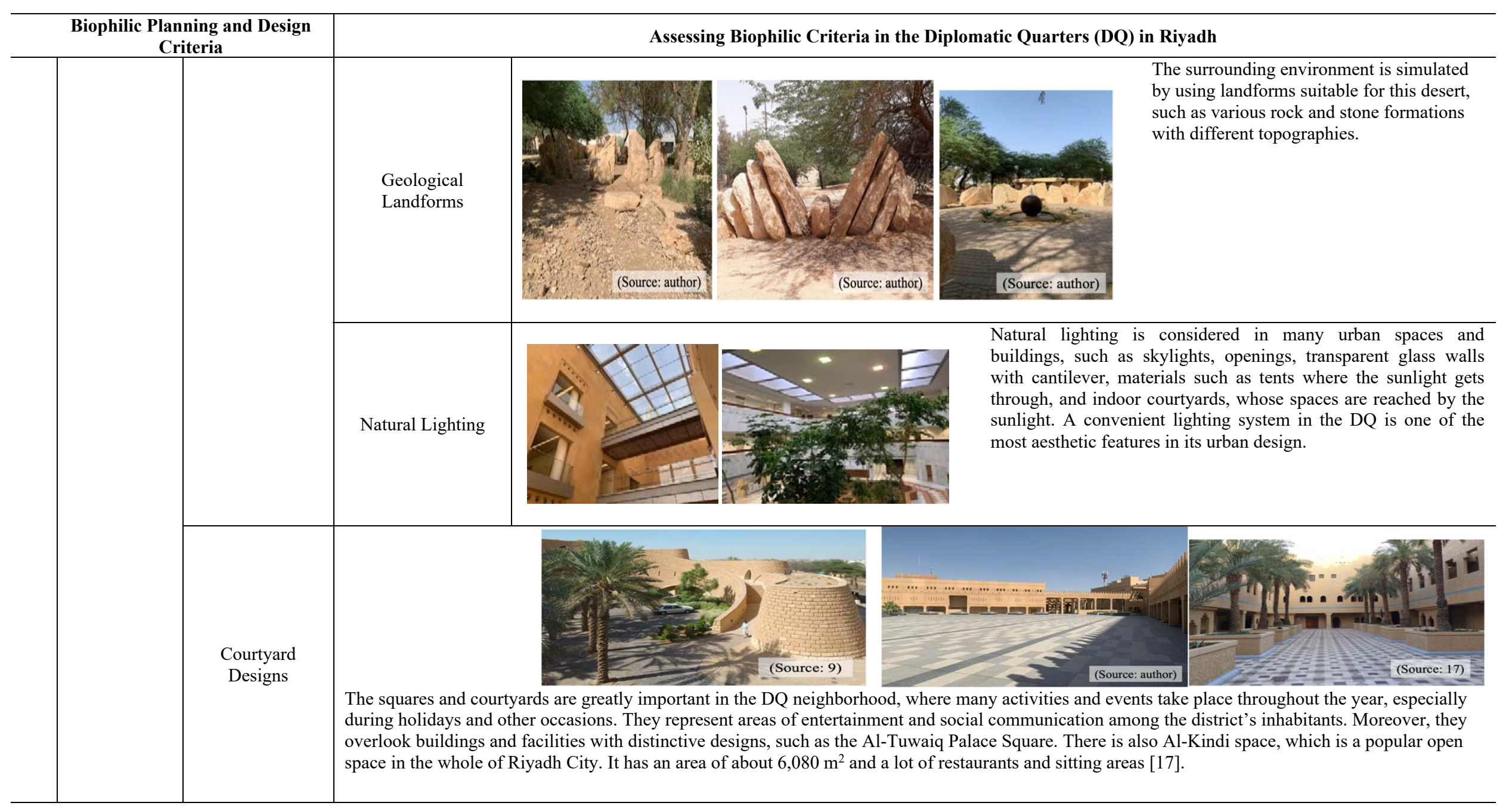

Source: Author 


\section{RESULTS}

In this section, the findings of the two stages of analysis used in this research study are discussed. The first part of the results is related to the Delphi technique, which was employed in the workshops of experts to identify the various criteria for the biophilic planning and design criteria. In the Delphi workshop technique, the experts were asked to choose and classify the different biophilic planning and design criteria into the main and sub-criteria to measure these chosen criteria in the DQ in Riyadh. Through several rounds of discussion, the experts reached to the most effective seven biophilic planning and design criteria, which consisted of fifteen sub-criteria that are based on the considerations mentioned in 3.2.1, to assess the achievement of the biophilic approach in the DQ in Riyadh.

The second part of the results is related to the measurement of these criteria in the DQ, in Riyadh City. It has been confirmed that the DQ has significantly achieved the criteria for the biophilic design and planning approach. This is evidenced by the many features obtained from the on-site observation conducted by the auther. The most important remarks are as follows:

First, the DQ analysis revealed that a large number of selected biophilic criteria were achieved, especially in the neighborhood's ability to preserve its identity and the integration between its urban environment and the surrounding environment. This is evidenced by the use of convenient building materials, such as stone and mud, the use of appropriate colors form nature, the presence of some natural formations from the neighborhood's original environment and its surrounding environment, and finally, the use of natural light and lighting elements that correspond to Riyadh's natural environment in general.

Second, one of the most important basic criteria for the biophilic approach was achieved, which is a sustainable green environment. This is evident in the diversity of the public parks, gardens, green spaces, and trees and plants used in the landscape; the neighborhood's connection with natural areas, such as Wadi Hanifa; and the use of water elements, such as fountains, which increase the sense of comfort for residents in the neighborhood.

Third is the diversity of the urban environment in the DQ neighborhood from the availability of mixed land uses, their integration, and the diversity of residential, recreational, and commercial uses; green areas; and public services.

Finally, the DQ and its urban environment are excellent study areas to learn from, towards a transition to sustainable neighborhoods in KSA. This is reflected in the establishment of programs and initiatives that aim to achieve sustainability principles, such as the Quality of Life Program and the Green Riyadh Project.

\section{DISCUSSION}

In this study, the biophilic approach in urban development in Riyadh, KSA, has been investigated through an analysis methodology of the various criteria. Such investigation has been conducted to enable the application of this development approach in the KSA and to measure the criteria in a residential neighborhood in Riyadh, the DQ. From this study, four main discussion areas have been determined.

First, the biophilic approach in urban development is a very significant concept that can be applied in urban environments similar to the environment in the KSA. The urban life in the KSA has numerous characteristics that make the biophilic approach one of the most sustainable solutions. Perhaps, one of the most important characteristics is the ancient history of the Kingdom with its religious and tribal dimensions, as well as the dry desert nature, which requires specific urban interventions to achieve the elements and requirements for sustainability.

Second, although there are various criteria for the biophilic approach, they can be classified into two main groups: planning criteria and design criteria. This study demonstrated the importance of both groups when applying the biophilic concept in the urban system in the KSA.

Third, this study, which was conducted in one of the districts of Riyadh to employ the biophilic approach, confirmed that the DQ is an excellent study area to learn from, towards a 
transition to sustainable neighborhoods in KSA. Moreover, this study confirmed the importance of this approach, consistent with the other studies.

Finally, this study discussed the great development programs that aim to achieve sustainability principles, such as the Green Riyadh Project and the Quality of Life Program. These programs also aim to improve the lifestyle of individuals and families and build a society that blends with its members. The Quality of Life Program is considered to be one of the 12 most important strategic programs in the KSA with the aim of achieving the goals of Saudi Vision 2030 and the idea of sustainability and biophilia. This program also seeks to include at least three Saudi cities in the list of the 100 best cities to live in the world by 2030 [44]. The program mainly depends on the quality of life in terms of two main aspects: lifestyle and liveability. From these two aspects, there are 10 main axes. The most important of these axes in the application of the biophilic approach are housing, urban design, and environment [44]. The third is the Green Riyadh Project, which aims to increase the per capita share of the green area with an increase in the percentage of the total green areas. This project is considered to be one of the largest projects that achieve the idea of sustainability in Saudi Vision 2030, as it aims to plant more than 7.5 million trees throughout Riyadh, in addition to the construction of 330 gardens in the neighborhoods, 43 public spaces, $1100 \mathrm{~km} 2$ green belts, and rehabilitation of $272 \mathrm{~km}$ valleys and tributaries [29] (Figure 5).

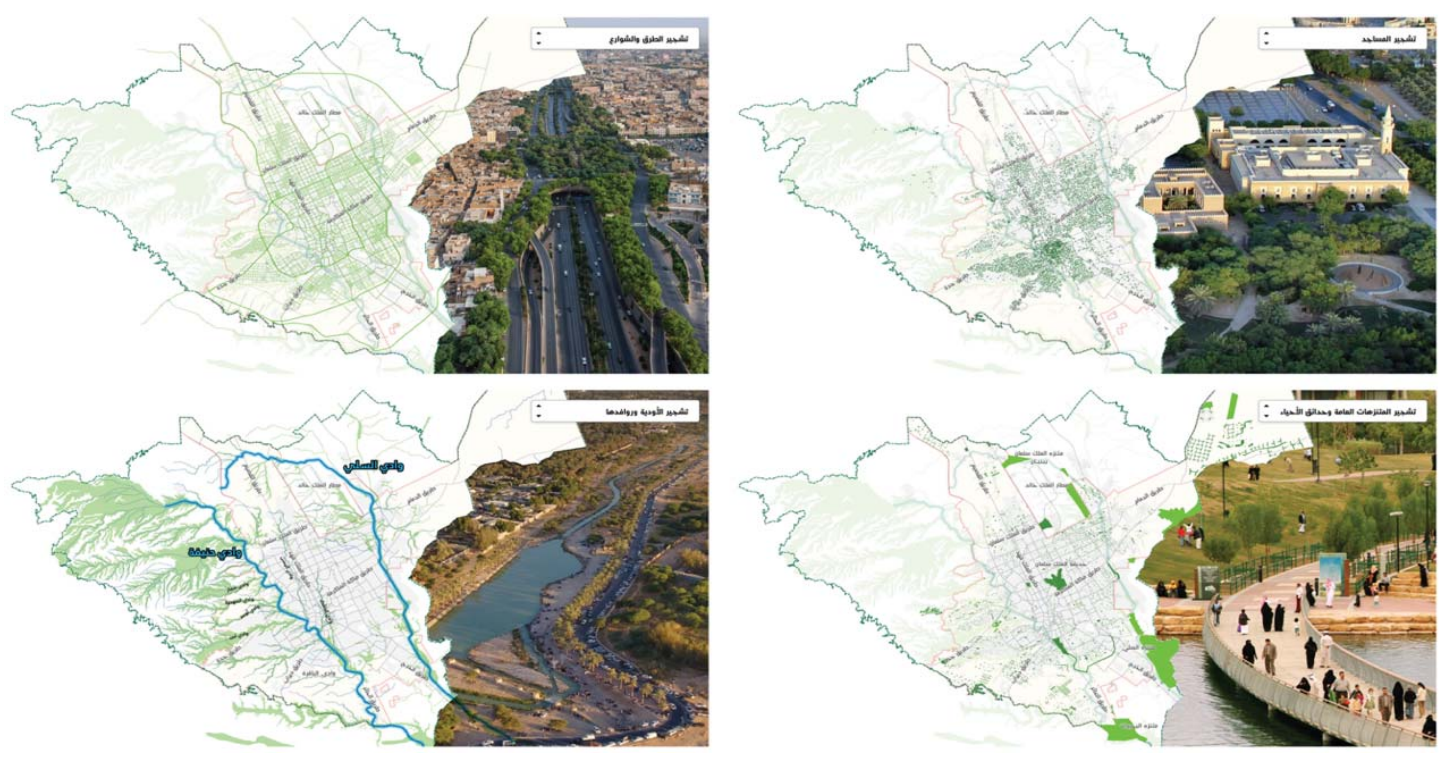

Figure 5. Green Riyadh Project feature maps (Source: [29])

\section{CONCLUSION}

This study aimed to identify the most important criteria of the biophilic approach in urban neighborhoods and use them to assess a neighborhood in Riyadh, namely, the Diplomatic Quarter (DQ).

By employing the Delphi technique in this study, the author found that there are many different and complex criteria for the application of the biophilic approach in urban development. However, these criteria differ, and their importance varies, depending on the geographical region in which this concept is applied. Hence, the author conducted a workshop, and the participants consisted of experts. They were instructed to classify and identifying the criteria that must be observed when applying the biophilic concept in the residential neighborhoods in Riyadh.

Although there are many criteria and standards for the application of the biophilia approach in urban design and planning, these multiple classifications of these criteria must be measured based on the context and physical urban nature of each country. Thus, for example, the criteria that may be important in the United States may not be as important in other countries. 
The application of the biophilic design and planning approach and the determination of how to correctly evaluate it in the KSA will impact the way the governments treat the natural environment taking into account sustainability approach. Moreover, the biophilic approach facilitates in achieving the sustainability principles and introducing nature into urban planning and design, and it is still participating in many programs and projects to achieve more urban sustainability in the country. Thus, further research should be conducted to evaluate the biophilic approach criteria in different countries and cities. This would enhance the understanding of all the dimensions of this sustainable development concept.

Funding: This research received no external funding.

Acknowledgments: the author is grateful to the Research Center of the College of Architecture and Planning, the Deanship of Scientific Research, and RSSU at King Saud University for their financial and technical support. The author would also like to extend his gratitude to the respondents and experts who participated in this study and took the time to share their experiences, opinions and comments during the Delphi Technique workshop survey. 


\section{Appendix A}

Table A1. Biophilic planning criteria features

\begin{tabular}{|c|c|c|c|c|}
\hline \multicolumn{4}{|c|}{ Biophilic Planning Criteria } & Features \\
\hline & \multirow{3}{*}{ 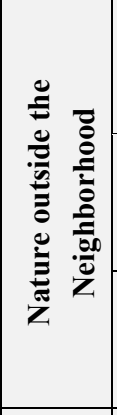 } & \multicolumn{2}{|c|}{ Transitional Areas } & $\begin{array}{l}\text { Transitional areas must exist around urban areas to separate and } \\
\text { make functional connections between the outside and inside areas } \\
{[30-31] \text {. }}\end{array}$ \\
\hline & & \multicolumn{2}{|c|}{ Tiered Planning Zones } & $\begin{array}{l}\text { There should be a natural environment near urban neighborhoods, } \\
\text { such as green corridors, to protect the community from harsh } \\
\text { environmental conditions [32]. }\end{array}$ \\
\hline & & \multicolumn{2}{|c|}{ Building Heights and Skyline } & $\begin{array}{l}\text { The heights of the buildings need to consider the surrounding } \\
\text { environment and natural phenomena, such as bird migration that } \\
\text { follows horizontal and vertical paths [5]. }\end{array}$ \\
\hline \multirow{10}{*}{ 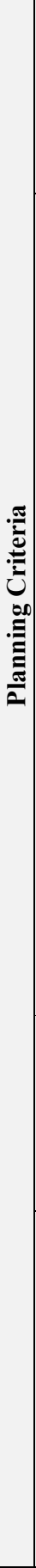 } & 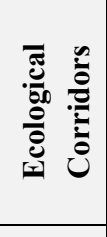 & \multicolumn{2}{|c|}{ Blue and Green Corridors } & $\begin{array}{l}\text { The presence of ecological (blue or green) corridors near the } \\
\text { biophilic urban neighborhoods should be considered. Moreover, } \\
\text { corridors should be connected to each other to prevent habitat } \\
\text { fragmentation and should be easily accessible and have pedestrian } \\
\text { paths and sitting areas with viewing spots [33]. }\end{array}$ \\
\hline & \multirow{4}{*}{ 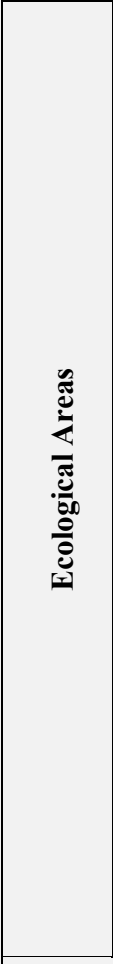 } & \multicolumn{2}{|c|}{ Surfaces and Green Buildings } & $\begin{array}{l}\text { Building materials suitable for the surrounding environment should } \\
\text { be used. In some areas, it is preferable to provide green buildings } \\
\text { with green surfaces [32]. }\end{array}$ \\
\hline & & \multicolumn{2}{|c|}{ Local Gardens } & $\begin{array}{l}\text { Majority of the buildings in the neighborhood should overlook } \\
\text { urban spaces (local gardens). These spaces should have a dynamic } \\
\text { and safe cover and provide some elements of visual connection to } \\
\text { each other [34]. }\end{array}$ \\
\hline & & \multicolumn{2}{|c|}{ Various Green Areas } & $\begin{array}{l}\text { The diversity of gardens in the neighborhood should be considered, } \\
\text { with conservation of the identity of the local ecological system. } \\
\text { Moreover, loss of identity and urban personality should be avoided: } \\
\text { (a) therapeutic gardens, which are often linked with health } \\
\text { institutions; (b) educational gardens, which provide external areas } \\
\text { for education and for practice of various activities; (c) enclave } \\
\text { gardens, which should be available in areas with multiple land uses } \\
\text { and wherein numerous activities take place; (d) recreational } \\
\text { gardens, which can achieve functional simulations of natural } \\
\text { elements and the surrounding environment [35]. }\end{array}$ \\
\hline & & \multicolumn{2}{|c|}{$\begin{array}{l}\text { Natural Area Inside the Urban } \\
\text { Area }\end{array}$} & $\begin{array}{l}\text { It is preferable to include aspects of the places' original } \\
\text { environment before the urban construction to preserve the memory } \\
\text { of the place and enhance the link between the inhabitants and the } \\
\text { original environment [36]. }\end{array}$ \\
\hline & \multicolumn{3}{|r|}{ פ } & $\begin{array}{l}\text { There must be diversity in land uses within the neighborhood, } \\
\text { which are not only limited to residential and commercial uses. All } \\
\text { uses must fall within an environmental development framework } \\
\text { that achieves ecological balance and ensures sustainability and } \\
\text { integration. }\end{array}$ \\
\hline & \multirow{4}{*}{ 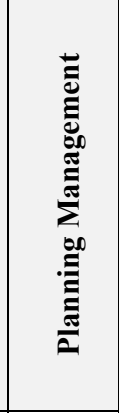 } & \multicolumn{2}{|c|}{ Waste Management } & $\begin{array}{l}\text { A closed system for the management of household waste, } \\
\text { especially organic, must be provided, as it is considered a habitat } \\
\text { for some unwanted organisms [31]. }\end{array}$ \\
\hline & & \multirow{3}{*}{$\begin{array}{c}\text { Wildlife } \\
\text { Manageme } \\
\text { nt }\end{array}$} & $\begin{array}{l}\text { Selection and } \\
\text { Classification }\end{array}$ & \multirow{3}{*}{$\begin{array}{l}\text { The use of reflective building materials should be avoided for } \\
\text { lighting, and a natural self-system must be installed to get rid of } \\
\text { pollutants on industrial and natural water surfaces. The basic } \\
\text { elements of the habitats in the natural environment surrounding the } \\
\text { urban neighborhood must be provided, and how to separate and } \\
\text { integrate between them and the constant urban development must }\end{array}$} \\
\hline & & & \begin{tabular}{|c} 
Prevent and Reduce \\
Damage
\end{tabular} & \\
\hline & & & \begin{tabular}{|c|} 
Identify and \\
Control Habitats
\end{tabular} & \\
\hline
\end{tabular}




\begin{tabular}{|c|c|}
\hline Biophilic Planning Criteria & Features \\
\hline Control Interaction & be identified [31-37]. \\
\hline
\end{tabular}

Source: Author

Table A2. Biophilic design criteria features

\begin{tabular}{|c|c|c|c|c|}
\hline \multicolumn{4}{|c|}{ Biophilic Design Criteria } & Features \\
\hline \multirow{10}{*}{ 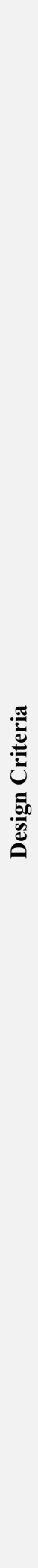 } & \multirow[t]{2}{*}{ 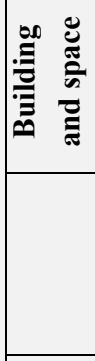 } & \multicolumn{2}{|r|}{ Building Designs } & $\begin{array}{l}\text { In general, the buildings should achieve aesthetic and functional } \\
\text { suitability with the surrounding environment by using suitable } \\
\text { building materials and colors and shades that are similar to the } \\
\text { surrounding environment. }\end{array}$ \\
\hline & & \multicolumn{2}{|c|}{ Urban Space Designs } & $\begin{array}{l}\text { The walls and edges of the spaces should be designed in a way } \\
\text { that they can support containment and partial closure. Moreover, } \\
\text { use natural human proportions should be used, especially those in } \\
\text { nature, such as the golden ratio }(1: 1,618)[38] \text {. }\end{array}$ \\
\hline & \multirow{8}{*}{ 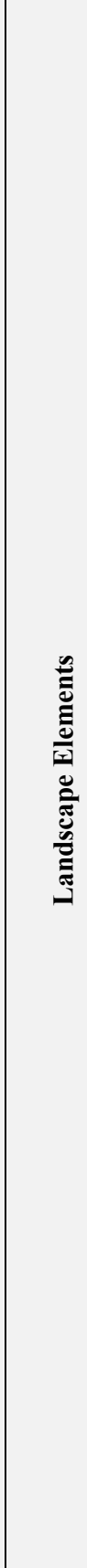 } & \multirow[t]{2}{*}{$\sum_{\tilde{E}}^{\mathscr{E}}$} & Design & $\begin{array}{l}\text { It is preferable to use curved paths, especially in park areas, and } \\
\text { use straight paths when needed. It is also necessary to provide } \\
\text { diversity and change in the scenery along a path to prevent } \\
\text { boredom and also to use different types of ground cover. In } \\
\text { addition, it is preferable to provide artificial hills to block the } \\
\text { visibility in some paths and enhance the feeling of curiosity and } \\
\text { exploration [5]. }\end{array}$ \\
\hline & & & Material & $\begin{array}{l}\text { Natural patterns should be preferably used, such as stones and } \\
\text { woods, as well as natural colors similar to the surrounding local } \\
\text { environment with regard to diversity. Also, water features, } \\
\text { especially in park areas, should be provided to allow for } \\
\text { ecological life through and inside them [5-38]. }\end{array}$ \\
\hline & & \multirow{5}{*}{ 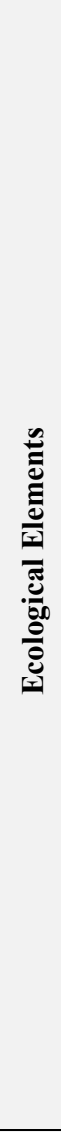 } & Land Cover & $\begin{array}{l}\text { Landscape ground covers in varying shapes, heights, and colors } \\
\text { should be used to provide various habitats. Diversification is also } \\
\text { preferable between deciduous and evergreen and flowering } \\
\text { landscape plants at certain times and seasons. Moreover, } \\
\text { landscapes should be distributed in a simulated nature and not } \\
\text { according to a specific geometric pattern [5]. }\end{array}$ \\
\hline & & & Animal Habitats & $\begin{array}{l}\text { Simulation of habitat designs, such as indigenous natural habitats } \\
\text { of target species, is preferable for protection and preservation. It is } \\
\text { also necessary to provide networks linking the ecological areas in } \\
\text { the community environment [39]. }\end{array}$ \\
\hline & & & $\begin{array}{l}\text { Water Features and } \\
\text { Elements }\end{array}$ & $\begin{array}{l}\text { Water elements with a variety of depths and impact should be } \\
\text { designed, and there should be diversity in the shape of the edges } \\
\text { of the water areas between the plant edges and rocky edges. The } \\
\text { water should be clean, purified, and renewable. The design of the } \\
\text { water elements should simulate nature and not follow a specific } \\
\text { geometric pattern. Also, moving water elements, not static ones, } \\
\text { should be used, such as fountains or artificial waterfalls [40]. }\end{array}$ \\
\hline & & & $\begin{array}{l}\text { Geological } \\
\text { Landforms }\end{array}$ & $\begin{array}{l}\text { Natural landforms in the surrounding environment should be } \\
\text { simulated, such as various rock formations [5]. }\end{array}$ \\
\hline & & & Natural Lighting & $\begin{array}{l}\text { An indirect natural dynamic light reflected from natural and } \\
\text { artificial moving shadows should be provided. There should be a } \\
\text { variety of shade types between shrubs, pergolas, and hanging } \\
\text { roofs. Fire should be used as a natural lighting element in a limited } \\
\text { and safe range as it has natural effects while adding a sense of } \\
\text { relief [5-38]. }\end{array}$ \\
\hline & & \multicolumn{2}{|c|}{ Courtyard Designs } & In the courtyard design, visual communication between the \\
\hline
\end{tabular}




\begin{tabular}{|l|l|l|l|}
\hline \multicolumn{2}{|c|}{ Biophilic Design Criteria } & \multicolumn{1}{c|}{ Features } \\
\hline & & & $\begin{array}{l}\text { courtyard elements and the surrounding environment is a major } \\
\text { criterion that needs to be applied, in addition to situating these } \\
\text { courtyards on a high plateau using appropriate natural proportions, } \\
\text { as well as providing areas for privacy [5]. }\end{array}$ \\
\hline
\end{tabular}

Source: Author

\section{REFERENCES}

[1] Al-Hemaidi, W. K. The metamorphosis of the urban fabric in an Arab-Muslim City: Riyadh, Saudi Arabia. Journal of Housing and the Built Environment. 2001,16(2), 179-201.

[2] Vision of the Kingdom 2030 (2016). Available online: https://vision2030.gov.sa/en/programs/HCDP (accessed on 7 May 2020).

[3] Choguill, C. L. Developing sustainable neighbourhoods. Habitat International. 2008, 32(1), 41-48.

[4] Kellert, S.R.; Wilson, E.O. The Biophilia Hypothesis; Island Press: Washington, USA, 1993; PP. 496.

[5] Kellert, S.R.; Heerwagen, J.; Mador, M. Biophilic design: The theory, science, and practice of bringing buildings to life, $1^{\text {st }}$ ed.; Jon Wiley \& Sons, Hoboken, New Jersey, USA, 2008; pp. 432.

[6] Kellert, S.R.; Calabrese, E. The Practice of Biophilic Design. 2015. Available online: www.biophilic-design.com (accessed on 18 April 2020).

[7] Lee, H.; Park, S. Assessment of Importance and Characteristics of Biophilic Design Patterns in a Children's Library. Sustainability, 2018, 10(4), 987. doi:10.3390/su10040987

[8] Kellert, S.R.; Heerwagen, J.; Mador, M. Dimensions, elements and attributes of biophilic design. In Biophilic design: The theory, science, and practice of bringing buildings to life, $1^{\text {st }}$ ed.; Jon Wiley \& Sons, Hoboken, New Jersey, USA, 2008; pp. 3-19.

[9] Royal Commission for Riyadh City (RCRC). Available online: https://www.rcrc.gov.sa/ar/ (accessed on 25 April 2020).

[10] Alshuwaikhat, H.; Mohammed, I. Sustainability Matters in National Development VisionsEvidence from Saudi Arabia's Vision for 2030. Sustainability. 2017, 9(3), 408. doi:10.3390/su9030408.

[11] National Transformation Program (NTP). Available online: https://vision2030.gov.sa/en/programs/NTP (accessed on 7 January 2020).

[12] Gehl, J. Cities for People, $1^{\text {st }}$ ed.; Island Press: Washington, USA, 2010; PP. 288.

[13] Madinah Region development Authority (MDA). Available online: https://www.mda.gov.sa (accessed on 17 March 2020).

[14] First International Conference on Humanizing Cities (2018). Available online: http://humancities.com/ar/ (accessed on 8 October 2019).

[15] Ministry of Municipal \& Rural Affairs (MOMRA, 2018). Available online: https://momra.gov.sa/ar/ (accessed on 5 April 2020).

[16] Future Saudi Cities Program (FSCP) Report, Riyadh City Review Report, UNHABITAT. Available online: https://www.futuresaudicities.org/wp-content/uploads/2017/07/RiyadhReview.pdf (accessed on 3 March 2020).

[17] Cardenas, M. G. The Diplomatic Quarters in Riyadh. A Western-shaped neighborhood in an Islamic city. International Planning History Society Proceedings, 17th IPHS Conference, History-Urbanism-Resilience, Delft, Germany, 2016; Entangled Histories of Cross Cultural Exchange, pp. 393-404.

[18] UN-World Population Prospects. Available online: https://population.un.org/wpp/ (accessed on 18 April 2020).

[19] Faisal, F. S. The Role of Urban Form in Sustainability — The Case Study of a Riyadh City Neighborhood. PhD Thesis, School of Architecture, Planning and Landscape, Faculty of Humanities and Social Sciences, University of Newcastle upon Tyne,2017. 
[20] Salazar-Elena, J.; Sanchez, M.; Otamendi, F. A Non-Parametric Delphi Approach to Foster Innovation Policy Debate in Spain. Sustainability. 2016, 8, 487. doi:10.3390/su8050487.

[21] Grisham. The Delphi technique: a method for testing complex and multifaceted topics. International Journal of Managing Projects in Business. 2009, 2, pp. 112-130. DOI: $10.1108 / 17538370910930545$.

[22] Hallowell, M.; Gambatese, J. Qualitative Research: Application of the Delphi Method to CEM Research. Journal of Construction Engineering and Management. 2010, 136, DOI: 10.1061/(ASCE)CO.1943-7862.0000137.

[23] Beatley, T.; Newman, P. Biophilic Cities Are Sustainable, Resilient Cities. Sustainability. 2013, 5(8), 3328-3345, DOI:10.3390/su508332.

[24] Signage and Information System Diplomatic Quarter Riyadh. Available online: https://www.unit-design.ch/en/projekte/dq-riyadh.php (accessed on 9 May 2020).

[25] ARRIYADH DEVELOPMENT AUTHORITY. Arriyadh Diplomatic Quarter - Design Brief. 2019.

[26] Envac's Pneumatic Waste \& Linen Collection System. Available online: https://bit.ly/2V81Dio (accessed on 8 May 2020).

[27] Waste Management World (WMW), Averda Deal to Provide Waste Collection \& Street Sweeping in Diplomatic Quarter of Riyadh. Available online: https://waste-managementworld.com/a/averda-deal-to-provide-waste-collection-street-sweeping-in-diplomatic-quarterof-riyadh (accessed on 12 May 2020).

[28] Habibi, A.; Sarafarzi, A.; Izadyar, S. The Delphi Technique Theoretical Framework in Qualitative Research. The International Journal of Engineering and Science (IJES). 2017, 3, pp. 08-13.

[29] Green Riyadh. Available online https://www.riyadhgreen.sa (accessed on 3rd August 2020).

[30] Kowarik, I. Novel urban ecosystems, biodiversity, and conservation. Environmental Pollution. 2011, 159(8-9), 1974-1983. DOI: 10.1016/j.envpol.2011.02.022.

[31] McKinney, M. L. Urbanization as a major cause of biotic homogenization. Biological Conservation. 2006, 127(3), 247-260. DOI: 10.1016/j.biocon.2005.09.005.

[32] Duany, A.; Talen, E. Transect Planning. Journal of the American Planning Association. 2002, 68(3), 245-266. DOI: 10.1080/01944360208976271.

[33] Chan, L.; Hillel, O.; Elmqvist, T.; Werner, P.; Holman, N.; Mader, A.; Calcaterra, E. User's manual on the Singapore Index on Cities' Biodiversity (Also known as the City Biodiversity Index). Singapore: National Parks Board, Singapore. 2014.

[34] Beatley, T. Biophilic Urbanism: Inviting Nature Back to Our Communities and Into Our Lives. William \& Mary Law School Scholarship Repository. 2009, 34:209.

[35] Aitken, R.; Looker, M. The Oxford Companion to Australian Gardens. Oxford University Press, United Kingdom, 2002; pp. 704.

[36] Zari, M. P. What makes a city 'biophilic'? Observations and experiences from the Wellington Nature Map project. Back to the future: The next 50 years, 51st International Conference of the Architectural Science Association, New Zealand, 2017. The Architectural Science Association and Victoria University of Wellington.

[37] Ditchkoff, S. S.; Saalfeld, S. T.; Gibson, C. J. Animal behavior in urban ecosystems: Modifications due to human-induced stress. Urban Ecosystems. 2006, 9(1), 5-12. DOI: 10.1007/s11252-006-3262-3.

[38] Browning, W.D.; Ryan, C.O.; Clancy, J.O. 14 Patterns of biophilic design, improving health \& well-being in the built environment. Terrapin Bright Green 1lc, New York. 2014.

[39] Beck, J. L.; Suring, L. H. Wildlife Habitat- Relationships Models: Description and Evaluation of Existing Frameworks. In Habitat Modeling Frameworks; USDA Forest Service Terrestrial Wildlife Ecology Unit, Washington, D.C., USA, 2009; 36.

[40] Williams, P.; Biggs, J.; Whitfield, M.; Thorne, A.; Bryant, S.; Fox, G.; Nicolet, P. The Pond Book: A Guide to the Management and Creation of Ponds, 2nd ed.; Ponds Conservation Trust; UK, 2010; pp. 111. 
[41] Peter Newman (2014) Biophilic urbanism: a case study on Singapore, Australian Planner, 51:1, 47-65, DOI: 10.1080/07293682.2013.790832

[42] [BB] SBEnrc (2012) Can biophilic urbanism deliver strong economic and social benefits in cities? An economic and policy investigation into the increased use of natural elements in urban design, Sustainable Built Environment National Research Centre (SBEnrc), Curtin University and Queensland University of Technology.

[43] Sam Gochman, (2015), SEEKING PARKS, PLAZAS, AND SPACES - THE ALLURE OF BIOPHILIA IN CITIES, TERRAPIN BRIGHT GREEN, NEW YORK CITY.

[44] The Quality of Life Program 2020 - Delivery Plan, Kingdom of Saudi Arabia.

[45] T. Beatley, Biophilic Cities: Integrating Nature into Urban Design and Planning, DOI 10.5822/978-1-59726-986-5_4, (C) Timothy Beatley 2011

[46] Albert Shpeer + Paartners. Available online: https://www.asp.com/projects/project/ueberarbeitung-des-masterplans-diplomatenviertel-r-68/show/ (accessed on 4th August 2020).

[47] Wolf, K. L., and K. Flora 2010. "Mental Health and Function: A Literature Review." In Green Cities: Good Health. Seattle: College of the Environment, University of Washington. www.greenhealth.washington.edu.

[48] Aspinall, Peter, Panagiotis Mavros, Richard Coyne, and Jenny Roe. 2013. "The Urban Brain: Analysing Outdoor Physical Activity with Mobile EEG.” British Journal of Sports Medicine. 49(4): 72-76.

[49] Atchley, R. A., D. L. Strayer, P. Atchley. 2012. Creativity in the Wild: Improving Cre- ative Reasoning through Immersion in Natural Settings. PLoS ONE 7(12): e51474. doi:10.1371/journal.pone.0051474.

[50] Donovan, Geoffrey, and David T. Butry. 2010. "Trees in the City: Valuing Street Trees in Portland, Oregon." Landscape and Urban Planning 94:77-83.

[51] Trust for Public Land (TPL). 2014, October. The Economic Benefits of San Francisco's Park and Recreation System.

[52] Browning, W.D., Ryan, C.O., Clancy, J.O. (2014). 14 Patterns of Biophilic Design. New York: Terrapin Bright Green 